\title{
The role of harvest, predators, and socio-political environment in the dynamics of the Taimyr wild reindeer herd with some lessons for North America
}

\author{
$\underline{\text { Leonid Kolpaschikov }}^{1}$, Vladimir Makhailov ${ }^{2}$ and Don E. Russell ${ }^{3}$
}

\begin{abstract}
The Taimyr wild reindeer herd, i.e., caribou (Rangifer tarandus), is one of the most important wildlife resources in the Russian Far North and may constitute the largest migratory Rangifer herd in the world. Over the last 60 years the herd has undergone a recovery from low numbers in the 1940s, reaching high densities by 1970 that concerned wildlife managers and domestic husbandry herds, with an $11.7 \%$ annual growth rate. At that time an aggressive commercial harvest of the herd was implemented, and organized wolf control was initiated with the goal of stabilizing herd numbers and injecting needed economic activity into the region. These actions dampened the rate of increase throughout the 1970s and 1980s to a 3.0\% annual growth rate. From 1991, after the collapse of the Soviet Union and the loss of financial capability to sustain the commercial harvest and continue wolf control, the population again increased at a 5.6\% annual growth rate, until peaking in 2000 at just more than 1 million animals. Since 2000 the herd has been in decline; harvesting, primarily unregulated, has increased; the wolf population has increased; and range conditions have deteriorated. Understanding what has occurred in the Taimyr range can provide North American managers with valuable lessons in understanding the large migratory herds on this continent, especially given that the social and political situation in Russia enabled intensive management, i.e., harvest and wolf control, that may not be able to be duplicated in North America.
\end{abstract}

Key Words: harvest; Rangifer; reindeer; Russia; Taimyr

\section{INTRODUCTION}

The Taimyr population of wild reindeer is the most numerous and economically important wildlife resource in the Russian Far North, occupying more than 1.5 million $\mathrm{km}^{2}$ in central Siberia (Kolpaschikov et al. 2003a). The population migrates from calving and summer ranges in the Taimyr Peninsula along three main migration routes to Taiga winter ranges that are distributed into western, central, and eastern segments (Fig. 1). From the early 1950 s until the end of the 20th century the population recovered from the very low numbers of the 1930s and 1940s. Throughout that growth phase, during which the population increased tenfold, managers faced many challenges and instituted a number of aggressive harvest regulations (Yakushkin et al. $1975 a, b)$. Initially the primary concern was to ensure the recovery of the Taimyr herd; therefore, hunting was limited. As the population increased, concerns shifted to overpopulation and conflicts with domestic reindeer; thus, harvesting was actively encouraged and facilitated (Syroechkovskii 1975). After the collapse of the former Soviet Union in the early 1990s, commercial harvesting became uneconomic and declined, and government agencies had few resources to monitor the herd and the harvest.

The main goals of the Russian State management system were to (1) protect small herds and rebuild populations where numbers dramatically declined, (2) maximize the economic benefit for local people within the ranges of large wild herds, (3) control numbers when herds are rapidly increasing to prevent overgrazing and outbreaks of infectious diseases, and (4) reduce conflict with domestic herds by preventing expansion of wild herds into reindeer husbandry areas (Klokov 2004). The main instruments to manage wild reindeer in Russia have been wolf predation and hunting quotas on state farms, where subsistence and commercial hunters were required to obtain permits from the state game service. Because the game service was not well staffed and the regions were very sparsely populated, it was difficult to issue
Fig. 1. The Taimyr wild reindeer range, central Russia, showing calving areas (grey polygon) and fall migration corridors (arrows). Map adapted from basemap supplied by Anna Pestereva (ARCSES Lab, University of Northern Iowa).

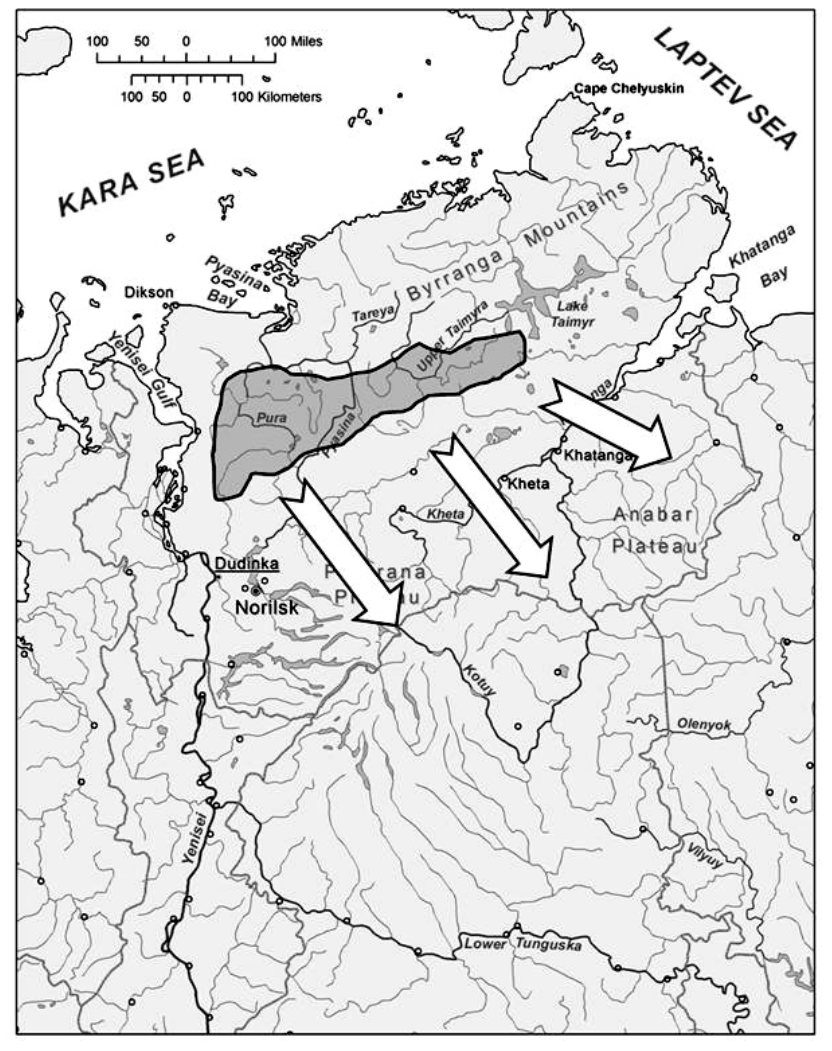


permits to all subsistence hunters. Consequently, most subsistence hunting was done without permits (Klokov 2004). Within the Taimyr range the majority of the harvest is currently conducted within four ethno-economic districts that reflect the predominance of ethnic peoples in each region: the Dolgans, Nenets, Nganasan, and the Evenki (Klokov 1997).

In North America the ability to institute the aggressive management actions that occurred in Russia with respect to harvest and wolf control is somewhat limited. There are a number of challenges to predator control, such as the inability of research to predict the benefits of wolf control on ungulate populations and the fact that public opinion increasingly supports the value of large predators (Schwartz et al. 2003). Few jurisdictions routinely practice wolf control (a notable exception is Alaska; see Boertje et al. 2010). Similar to the situation in North America, indigenous peoples in Russia have a mixed cash-subsistence economy, and before the settlement of indigenous land claims, most regulations were developed and implemented by the state and federal ministries with little local consultation (Russell and Ulvevadat 2004). However, unlike North America, most harvest in Russia is commercial rather than subsistence (Klokov 2004, Kofinas and Russell 2004). Thus, the large-scale harvest programs described in this paper are not likely feasible within the range of many herds in North America. In fact, many land claim settlements contain provisions to prohibit the commercial harvests of large caribou (Rangifer tarandus) herds (Kofinas and Russell 2004).

The lessons learned from examining what was done with the Taimyr herd and how it responded provide a valuable case study for North America. Agencies and comanagement boards responsible for making recommendations for herds undergoing significant numerical fluctuations need to know how harvesting impacts the population dynamics of these large migratory herds.

In this paper we summarize 50 years of data regarding population size, vital rates, harvest levels, and predation and predator control. These data are located in scattered Russian publications or in unpublished field reports of the first two authors. Our goal was to tie together existing data to better understand the dynamics and subsequent management actions of one of the world's largest migratory tundra herds.

\section{SOCIOECOMONIC PERIODS AND MANAGEMENT FOCUS}

To compare management actions and herd response, we divided the period from the 1950s to the present into three phases: (1) the precommercial period, from the 1950 s to 1970 ; (2) the commercial period, from 1970 to 1990; and (3) the postcommercial period, from 1991 to the present (Mikhailov and Kolpaschikov 2012).

\section{Precommercial period from the 1950s to 1970}

Findings of surveys show that the Taimyr population dramatically declined from about 400,000 in the 1930s and 1940s and then began to increase in the early 1950s (Yakushkin et al. 1975a). The first modern survey determined that there were about 110,000 reindeer in 1959 (Yakushkin et al. 1975b). From the late 1950 s to late 1960 s the hunting quota of 5000 - 6000 animals was determined based on the needs of indigenous people. The permits were only allocated to the indigenous population of the Taimyr and Evenkia regions. There was little monitoring of the harvest, and estimates were based on the number of licenses issued and estimated poaching loss.

The relatively low unorganized subsistence harvest by indigenous groups was thus estimated between 4000 and 5000 animals, primarily at river crossings and mountain passes (Skrobov 1975). Industrial development in the region was low and dispersed. The wild reindeer population began to increase, with subsequent counts estimating a population of 252,000 in 1966 and 330,000 in 1969 (Yakushkin et al. 1975b), an 11.7\% annual rate of increase. During this period monitoring indicated that the adult females were in excellent shape and very productive (Yakushkin et al 1975b). In the Taimyr, indigenous people had long practiced subsistence hunting at river crossings. However as the herd grew, hunting was banned at river crossings to prevent overharvest during herd recovery (Nuttall et al. 2102). This ban was in effect until the commercial period, when harvesting became a population regulation tool.

Coincident with the increase in wild reindeer numbers was an increase in the domestic production of reindeer through organized state farms and collectives (Geller and Borzhonov 1975). In the precommercial period more funding was available for research on and marketing of domestic reindeer, and few resources were available to monitor the wild population (Syroechkovskii 1975). However, numerous evaluations of pastures (Andreev 1975) and food habits (Mukhachev 1975), and observations of wild and domestic reindeer interactions resulted in concerns being raised about the continued growth of the wild population in the late 1960s. These studies were used to evaluate the carrying capacity of the Taimyr range for wild and domestic reindeer. Andreev (1975) reported that domestic reindeer made much more efficient use of the range than wild counterparts and expressed the concern that self-regulated wild populations have historically caused significant damage to their range, requiring long periods of time to recover.

Kolpaschikov (1974) and Mukhachev (1975) noted that lichen constituted only $11 \%-22 \%$ of the winter diet of wild reindeer compared with more than $70 \%$ for domestic reindeer. They also noted that wild reindeer caused significant trampling of lichen pastures. From 1966 to 1970, more than 27,000 domestic reindeer joined the wild herds in the Taimyr, further raising concerns about the collapse of the domestic industry (Roslyakov 1975). Geller and Borzhonov (1975) maintained that by the end of the 1960s, $75 \%$ of the domestic pastures were overlapped by wild reindeer, but concluded that the number of domestic reindeer lost to wild herds was largely dependent upon the type of management and protection herders used for their domestic herds. Studies during this period determined a carrying capacity of 450,000 reindeer in the Taimyr region, 116,000 domestic, and 340,000 wild (Syroechkovski 1995).

During the precommercial period, wolves were thought to number around 400, and reindeer herders and hunters actively killed wolves that were associated with their herds and/or activities. On average about 200 - 250 wolves were harvested annually during this period. This harvest of wolves, combined with harvest restrictions on wild reindeer, was thought to be the primary reasons for the rapid growth in the wild reindeer population. 
By the end of the 1960s, the wild reindeer population was rapidly increasing, and the domestic industry was feeling pressure. There were signs that the wild population had reached range carrying capacity because of a major shift from eastern ranges to western ranges and high subadult mortality (Geller and Borzhonov 1975). In addition, there was increased human industrial activity in the region (Skrobov 1975). In 1974 Syroechkovskii (1975) set up a commission to implement and oversee a major increase in commercial harvest of wild reindeer in the Taimyr population to avoid a major catastrophe, as expressed by N. D. D'yachenko of the Far North Agricultural Research Institute:

\section{If we do not solve the problem of the wild reindeer soon, then in seven to ten years there will be neither wild nor domesticated reindeer in Taimyr, since the available pastures will have been decimated and decades required to restore them as a fodder base for reindeer husbandry (Roslyakov 1975:237).}

\section{Commercial period from 1970 to 1990}

Significant efforts began in the early 1970s to actively promote commercial harvest of Taimyr's wild reindeer in response to concern about overexploitation of the range by a growing wild population (Klokov 1997). This response was made to avoid conflicts with the domestic reindeer industry and to obtain some economic benefits from an expanding wild population (Syroechkovskii 1975). The majority of the harvesting was conducted at river crossings by hunting brigades located along the Piasina and Kheta rivers, at the distance of $15-20 \mathrm{~km}$ between each brigade (Klokov 1997).

To help facilitate the high commercial harvest during the $1970 \mathrm{~s}$ and $1980 \mathrm{~s}$, the state constructed and supported more than 50 slaughterhouses, and 20 underground ice houses and other storage facilities were built in the tundra along the rivers where harvesting occurred. During winter, when the river was frozen, hunting continued on land. In many places, special fences were constructed to guide the wild reindeer herds into corrals, where they were harvested (Laishev et al. 2002, Klokov 2004). A significant number of wild reindeer were shot from helicopters (Klokov 1997). Although some wild reindeer meat was consumed by indigenous peoples of the Taimyr and Evenkia Autonomous Area, most of the harvested wild reindeer were transported to the cities of Norilsk and Dudinka, where the Norilsk Combine Trade Department constructed refrigerators and storage facilities for meat products. This meat was processed and consumed by the residents of the Norilsk industrial region. The wild reindeer meat was not transported to other cities in Russia, nor was it exported internationally.

Prior to 1970 there was primarily a subsistence hunt of Taimyr wild reindeer, with modest commercial industry. After 1970 hunting became primarily a commercial activity involving far more urban hunters than indigenous hunters (Pavlov et al. 1976). The cost of transporting meat, largely with helicopters, was low because of state subsidies. In fact during the commercial period the money derived from the harvesting of the wild population far exceeded output from the small domestic reindeer breeders of the Taimyr and Evenkia regions (Syroechkovskii 1995). This situation contrasts with the precommercial period, when the economic yields from domestic and wild reindeer were comparable (Syroechkovskii 1975). By the end of the 1980s, only about 60,000 domestic reindeer remained within the range of the Taimyr wild reindeer herd, a 50\% decline from previous decades (Laishev et al. 2002). The herding of domestic reindeer was considered important only as a socially stabilizing factor for indigenous peoples who had a cultural identity with reindeer husbandry (Klein and Kolpashikov 1991).

As a consequence of the significant commercial investments and returns in the wild reindeer population, monitoring of the herd was much more active than it was in previous decades. Despite a significant increase in harvest throughout the 1970s and 1980s, the herd continued to increase from 330,000 to 670,000 by 1993 (Fig. 2), a 3\% annual rate of increase. Harvest peaked in 1988 with 120,000 animals taken (Fig. 3; Kolpaschikov and Mikhailov 2002).

Fig. 2. Population estimates of the Taimyr wild reindeer herd 1959-2009. Estimates for 2003 and 2009 were based on aerial surveys combined with expert opinion because coverage was incomplete.

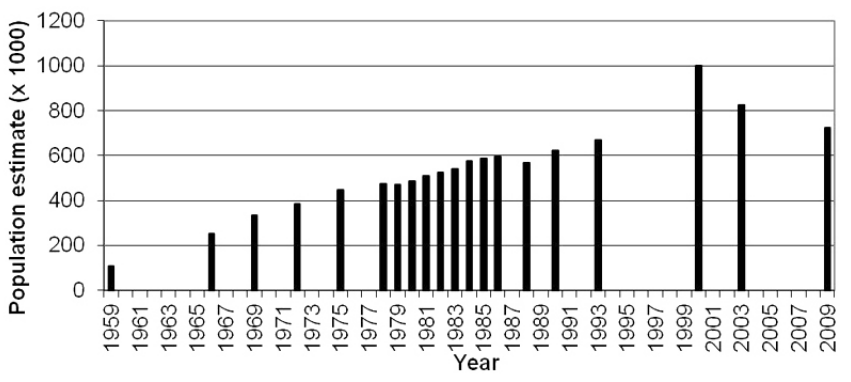

Fig. 3. Estimated harvest of the Taimyr wild reindeer population from 1959 to present. Note: in the precommercial period the harvest was not monitored and was assumed to equal the number of permits issued based on local indigenous needs. From 1972-1995 numbers were based on formal harvest surveys. Estimates after 1995 were based on expert opinion (L. Kolpaschikov) during this period of uncontrolled hunting.

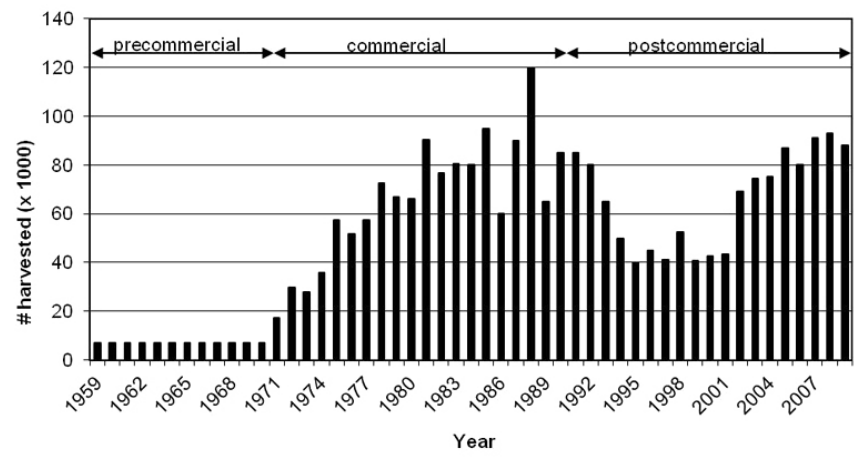

As part of sustaining the commercial harvest program, wolf management aimed to dramatically reduce the wolf population within the herd's range. Not only were wolves killed during harvesting operations and incidental to reindeer herding, but state 
agencies used an active aerial hunting program to reduce wolf numbers. Even though it was expected that the wolf population would increase in response to increased wild reindeer numbers, the active wolf control program was thought to stabilize and even reduce wolf numbers. On average through the 1970s and 1980s, $500-600$ wolves out of an estimated population of 1500 wolves (Klein and Kolpashikov 1991) were removed annually within the range of the Taimyr herd.

\section{Postcommercial period from 1991 to the present}

The chain of events that eventually led to the collapse of the Soviet Union had dramatic ramifications for the management and exploitation of the wild Taimyr reindeer herd (Baskin 2005). The state's financial support for harvest and management of both the wild and domestic populations was eliminated (Kolpaschikov et al. 2003b, Baskin 2005). For the commercial harvesting of the wild population, the change meant that the era of cheap transport, mainly the use of helicopters, was over (Klokov 2004). Whereas population estimates were attempted annually during the commercial period, after 1991 there was no money available for a population count until 2000, when an estimate of more than 1 million wild reindeer was reported (Yakushkin et al. 2001). This constituted an annual increase between 1993 and 2000 of $5.6 \%$. Intensive commercial harvesting stopped abruptly following the dissolution of the Soviet Union, and an era of unsubsidized, unregulated hunting of wild and domestic reindeer ensued. Compared with the commercial harvest in the 1980s, the harvest in Taimyr after 1991 was estimated to have been reduced by $45 \%$ - $50 \%$ based on the best estimates of researchers in the field (Kolpaschikov et al. 2003b). Private hunting began to increase in 2000 . In the period from 2005 to 2010 , about 85,000 reindeer were harvested by hunting annually. This number is almost twice the quota set by the state (Fig. 3).

Aerial hunting of wolves and the use of specialized on-the-ground wolf hunting squads stopped because of a lack of funding. At the same time, the population of wild reindeer rapidly increased, improving the prey base for the wolves. As a result, the number of wolves and predation rates grew, based on aerial and tracking surveys, to an estimate of 3000-3500 by 2000 (Suvorov 2001a), with predation of up to 50,000 to 60,000 wild reindeer annually. As the wild reindeer population declined, and with wolf numbers still high, managers estimated that by 2009 wolves were responsible for more than $30 \%$ of the annual wild reindeer mortality.

\section{HERD MONITORING}

\section{Population trends}

Population estimates of the Taimyr herd have been conducted primarily on the tundra during the summer because large aggregations form in response to insect harassment. An attempt is now being made to count the entire herd either directly or through the use of aerial photography. Aerial surveys from 1969 to 2000 included reconnaissance flights to locate concentrations of animals, followed by formal survey flights. During survey flights at least three aircraft were used to photograph summer aggregations. Scattered groups outside of the aggregations were estimated from reconnaissance flights and incidental to formal survey flights. Incorporating extrapolation of scattered groups resulted in a $\pm 5 \%$ confidence interval for years with favorable weather conditions and $\pm 10 \%$ under weather adverse conditions. The age and sex structure of the population were determined from cementum age of incisors (Laws 1952) collected during hunting activities. Life tables were then constructed to estimate agespecific mortality rates (Kolpashchikov and Mikhailov 2001).

The initial survey in 1959 estimated 110,000 animals. The herd grew at a rate of $11.7 \%$ per year until 1975 , the beginning of the commercial harvest period. After 1975, the rates of growth declined considerably, increasing an average of $3 \%$ annually between 1978 and 1990. Between 1986 and 1990, the herd stabilized (Fig. 2). During the commercial period, population estimates from field surveys were not possible every year. Thus, in years between surveys, population size was calculated based on productivity and mortality data.

The collapse of state-subsidized hunting beginning in 1991 resulted in a substantial decline in harvesting and led to rapid growth of wild reindeer numbers. The aerial survey in 2000 was held under extremely favorable weather conditions, and approximately 1 million wild reindeer were counted, representing an annual rate of increase of $5.6 \%$ between 1993 and 2000 (Yakushkin et al. 2001) and exceeding what was considered the carrying capacity of the range, which was 850,000 - 900,000 animals (Kolpaschikov et al. 1983). After 2000, the herd started to decline based on estimates made in 2003 and 2009. The 2003 survey was incomplete. About 600,000 wild reindeer were in the surveyed area; however the entire range was not covered. Based on on-the-ground expert opinion, the total number of animals was more likely between 800,000 and 850,000 (Kolpaschikov and Muhachev 2010; L. A. Kolpaschikov, personal observation). Similarly a total count could not be completed during the 2009 survey, primarily because the large aggregations had started to disaggregate. About 500,000 wild reindeer were counted in the surveyed area. The first two authors of this paper believe the total population on the summer ranges, i.e., west, central, and eastern Taimyr, was not fewer than 700,000 - 750,000 animals. Similar results were obtained from a population model developed by the first two authors, based on vital rates measured in the field.

\section{Harvest trends}

In the commercial period of 1970-1990, the quota and harvestable surplus were calculated as the difference between recruitment and mortality, i.e., equal to the potential growth rate of the herd. The actual level of harvesting was almost always lower than the science-based quotas, so the population increased, but at a much lower growth rate than would have been realized in the absence of hunting (Mikhailov et al. 2008). After the commercial period, the quotas were also based on the management goal of stabilizing the population. However, the small staff and limited financial resources meant that the state could no longer monitor the herd and control hunting. Initially the commercial hunting dropped dramatically, whereas the subsistence hunt probably increased (Mikhailov et al. 2008). The best estimate from experts is that from 70,000 to 90,000 wild reindeer are presently being harvested annually from the population, including unpermitted hunting and wounding loss. Thus, the current total harvest greatly exceeds the official quotas being set (Fig. 4). 
Fig. 4. The percent of quota actually harvested in the Taimyr reindeer herd from 1959-2010. Note: in the precommercial period harvest was not monitored and was assumed to equal the number of permits issued based on local indigenous needs.

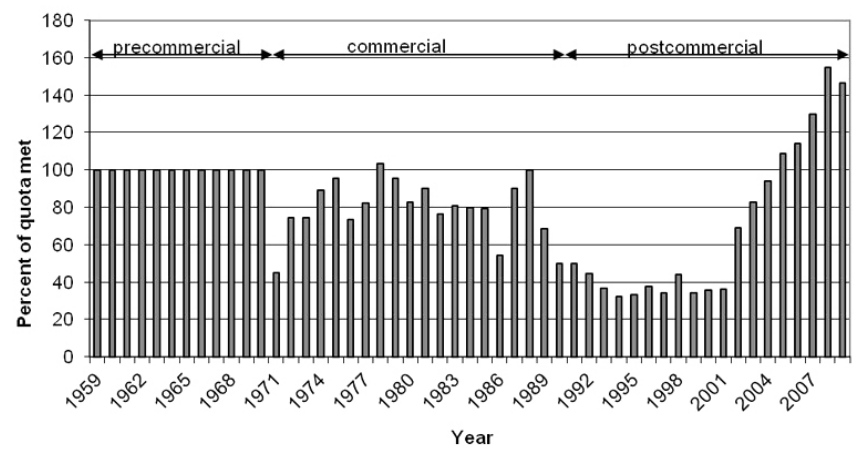

\section{Pregnancy rates}

The intensive monitoring of the herd coincided with the initiation of commercial harvesting. Pregnancy rates generally averaged more than $77 \%$ during the commercial period, but dropped considerably in the postcommercial period to an average of $64.5 \%$ (Fig. 5). The reduction in the pregnancy rate after 1990 has been attributed to deterioration of pastures, leading to poorer body condition of adult females. In addition, the high harvest of females in the fall has led to surviving female calves in poorer condition, translating into older age of first reproduction and/or birth of calves to a weak cohort of young cows.

Fig. 5. Pregnancy rates of the Taimyr reindeer population 1977-2010. All data based on combination of composition count surveys during calving and animals collected in the field.

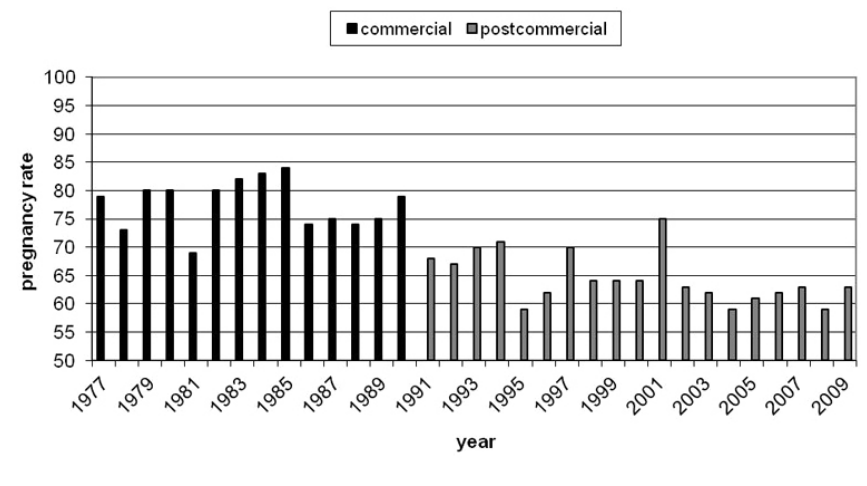

Herd productivity and harvestable surplus

Measures of productivity of the Taimyr herd from 1969 to 2009 were determined from measured or modeled values (Kolpaschikov and Muhachev 2010). Potential productivity was defined as the number of calves in late summer, just after the annual population estimate; harvestable surplus was defined as the difference between potential productivity and natural mortality; and actual harvest was defined as the total subsistence and commercial harvest recorded (Fig. 6). In the postcommercial period, monitoring and control of age and sex in the harvest were no longer being done; the main criterion was the need to get meat to market. Currently it is thought that too many males are being taken; thus, low bull-to-cow ratios are being measured in the population as a whole, causing some concern for the future productivity of the herd.

Fig. 6. Potential productivity, harvestable surplus, and actual harvest of the Taimyr wild reindeer herd, 1969-2010. Estimates were derived from aerial population estimates during census years and modeling extrapolation in nonsurvey years.

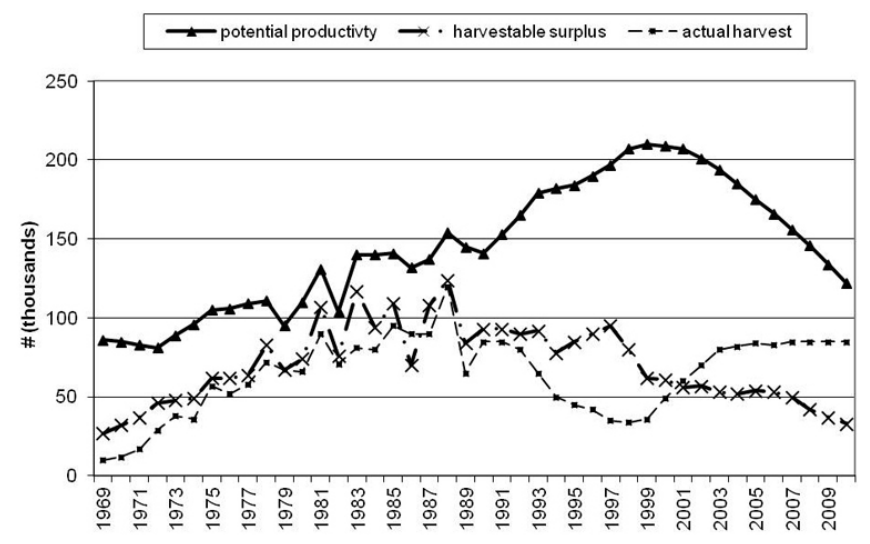

In terms of harvest management, if the objective was to stabilize the herd, the harvestable surplus would represent the total commercial and subsistence harvest quota for any given year. From Figure 6 we can see that the actual harvest did approach the harvestable surplus in the commercial period of 1970-1990. In contrast, after 2000 actual harvest exceeded harvestable surplus, coinciding with a declining herd (Fig. 6).

The ratio of harvestable surplus to total population size is a measure of the harvest potential of the herd. From 1969 to 1978 the percentage of the herd available for harvest varied between $11 \%$ and $13 \%$ of the population size. From 1978 to 1990 , during high commercial harvests and active wolf hunting, this percentage rose to $15 \%-17 \%$, associated with a reduction of predators, relatively high pregnancy rates (see Fig. 5), low incidence of disease, and good range conditions. With such productivity, the hunting quota would be around 90,000 animals, assuming a goal of a stable population and with a preharvest population of 600,000 caribou.

Since the end of the 1990s, the ratio of harvestable surplus to population size dropped to $5 \%-6 \%$ of the population, resulting in a stable harvest quota of 30,000 with a population size of 600,000 (Fig. 7). This low proportion is associated with an increased wolf population, declining pregnancy rates, deteriorating range conditions, and an increased incidence of disease. Herd declines after 2004 were associated with harvests far exceeding the 30,000 sustainable harvest quotas (see Fig. 4). 
Fig. 7. The harvest potential of the Taimyr wild reindeer herd 1969-2010. Harvest potential is the ratio of harvestable surplus (from Fig. 6) to total population size with a goal of zero population growth.

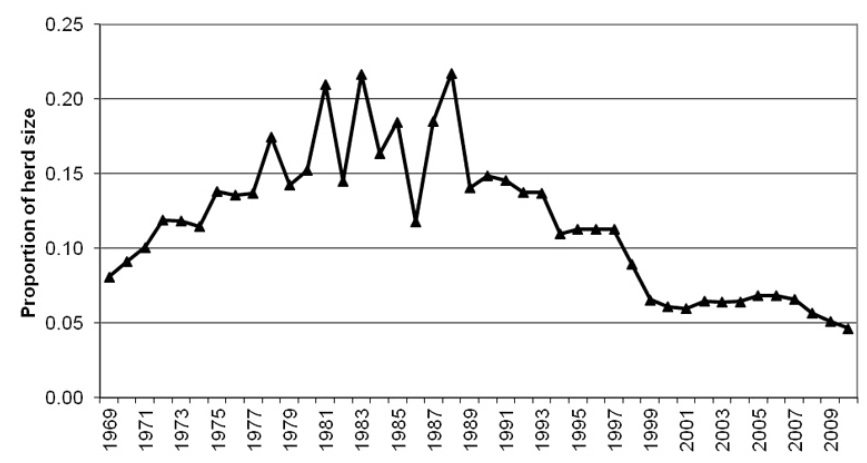

During the beginning of the commercial period, managers, including the first author of this paper, thought that it was important to maintain the natural age and sex ratio in the herd. To accomplish this, hunters were instructed to harvest all animals in the group as they were encountered. As the harvest was monitored further, increased quotas were allotted if a certain age or sex needed to be targeted. Currently, with unregulated harvests, maintaining sex and age ratios through targeted hunting is no longer possible.

\section{Wolf predation and control}

Wolf densities have been estimated from aerial surveys conducted by wildlife staff in the region, based primarily on tracking in the winter in various regions and during various time periods within the range of the Taimyr wild reindeer population. In the tundra regions there are approximately 1.5 wolves per $1000 \mathrm{~km}^{2}$, whereas in the western forest region where a few wild reindeer summer and migrate, there are closer to 2.5 wolves per $1000 \mathrm{~km}^{2}$. On northern Taiga ranges where the majority of wild reindeer winter, there are about 12.7 wolves per $1000 \mathrm{~km}^{2}$. The highest wolf density, 20 wolves per $1000 \mathrm{~km}^{2}$, is found in the Putorana mountains, although densities can be as high as 45 wolves per $1000 \mathrm{~km}^{2}$ (Suvorov 2003). To calculate the number of wild reindeer killed by wolves, Suvorov (2005) indicated that 1 wolf can kill up to 14 wild reindeer throughout the winter. Considering that about $50 \%$ of the wolves migrate to the tundra with the wild reindeer in the spring, we calculated that those wolves consume an average of 17 wild reindeer each.

During the 1950s, the number of wolves in the Taimyr range was approximately 400 , with a high proportion of these, $200-250$ wolves per year, killed annually by hunters and herders. We believe that the high harvest of the wolves played a major role in the rapid recovery of the reindeer population during this period. During the commercial period, wolf numbers did not increase dramatically because of the increased effort to limit wolf numbers. During this period, up to 500 wolves were taken per year, which maintained the wolf population at a stable size of around 500 600 individuals. After 1990, when funding was no longer available to harvest the wolves, wolf numbers increased significantly, growing to an estimated 3000 - 3500 individuals by 2000 (Suvorov 2001b).

Throughout the commercial period, under strong wolf control measures, wolf predation resulted in an average of $30.6 \%$ of the natural and $11.2 \%$ of the total mortality of wild reindeer (Fig. 8). After the reduction in wolf control measures, that contribution increased to $32.6 \%$ and $22.7 \%$, respectively, by the time the herd peaked in 2000, and subsequently dipped coincident with deteriorating range and increase in disease and parasites. With current declining numbers of wild reindeer, the contribution of wolf predation to total mortality is once again on the rise, exceeding $60 \%$ of natural and $30 \%$ of total mortality in 2010 (Fig. 8).

Fig. 8. Predation rate by wolves where: "wolf predation rate" is proportion of total population size; "wolf:total mortality" is the proportion of total mortality attributed to wolves; "wolf: natural mortality" is the proportion of nonharvest mortality attributed to wolves. Wolf population estimates are derived from a number of systematic surveys in representative habitats (tundra versus taiga, for example) and extrapolated through expert opinion to the range of the Taimyr herd.

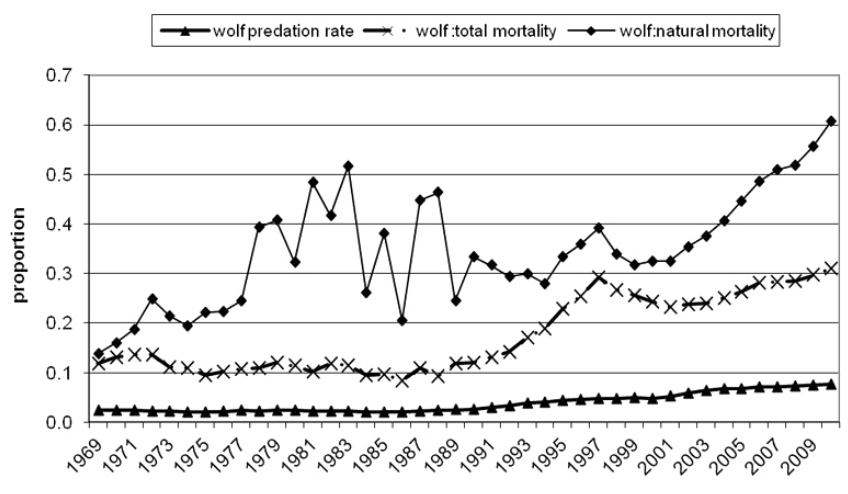

\section{Lichen ranges}

In contrast to many North America herds, lichens are not the predominating forage of wild reindeer, with the proportion in the diet not normally exceeding 30\%. However, we think the health of the lichen pastures is still considered a measure of the health of the winter ranges of wild reindeer in the Taimyr Peninsula. At the beginning of the commercial period, Shelkunova $(1982,2000)$ estimated the damaged lichen ranges exceeded one million hectares, primarily because of poor grazing practices of herders and trampling and consumption by wild reindeer in the regions where domestic and wild reindeer overlap in winter. Since that period, damage to lichen pastures has increased not only because of a dramatic increase in the wild reindeer population but also because of increased human activity in the region (Pikuleva and Zhiganova 2003). Contamination by the smelting activities in Norilsk has resulted in destroyed vegetation cover downwind of Norilsk of more than 565,000 hectares. Human activity has also increased the incidence of forest fires, destroying lichen understory. Between 1970 and 2000, more than 700,000 hectares burned. In total, according to the Regional Committee on Land Resources, over 
this same 30 -year period close to 5 million hectares of lichen range suffered a reduction in capacity because of all the drivers of change, which represented close to $50 \%$ of the Taimyr wild reindeer winter range.

\section{DISCUSSION}

The Taimyr wild reindeer population response to wolf control and harvest commercialization is useful to North American managers in understanding the dynamics of humans and large migratory populations of Rangifer. During the commercial period of this study, data indicated that with high harvest in conjunction with high wolf removal (1) the highest herd net productivity was recorded, (2) a large herd in excess of 600,000 animals could be stabilized, and (3) managers could delay the population peak for a number of years. This latter point needs explanation. Managers were noting signs that the Taimyr population was on the verge of peaking in the early to mid 1990s. The range was being rapidly depleted; pregnancy rates were declining; average weight of pregnant females was declining; range shifts were observed, i.e., the herd shifted back to the eastern ranges after shifting west in the 1950s; and disease, especially brucellosis, was increasing. However despite these negative trends, the herd increased rapidly throughout the 1990s after the commercial harvest declined and wolf control was no longer financially supported. In the absence of active management, the herd did finally reach a peak in 2000 .

Populations of migratory Rangifer are known to undergo extended periods of abundance and scarcity (Gunn 2003) even if no management actions are taken. When herds are increasing, there are few examples in North America of aggressive management actions to control population growth. However, during recent caribou declines in North America, agency managers and comanagement boards were expected to initiate management actions to either halt the decline of the herds or reduce the recovery time. Experience in that period revealed that under the management regimes in place, response was slow and hampered by (1) mistrust of government surveys; (2) disagreement amongst outfitters, resident hunters, and indigenous hunters as to how harvest reductions should be applied; and (3) slow governance processes to implement management actions.

\section{Harvest as a management tool}

The vast majority of harvest in Russia is typically commercial, with limited subsistence harvest (Klokov 2004). Although caribou in North America were commercially harvested during the gold rush and in conjunction with early trading posts, overall the practice is viewed as against indigenous values (Kofinas and Russell 2004). Although the practice varies, some jurisdictions, e. g., Alaska and parts of northern Canada, specifically prohibit the commercial sale of caribou, i.e., wild reindeer. For those jurisdictions where commercial hunting is allowed, such hunts fall into three categories; small-scale market hunting, organized community hunts, and large-scale commercial hunts. The latter enterprise, which compares with the commercial hunts practiced in the Taimyr region, has had limited success in North America, primarily because of restrictions in the handling and marketing of meat, the costs of transportation, and the limits posed by formal claims agreements (Kofinas and Russell 2004).
In this study the state not only encouraged large-scale commercial harvest, but also facilitated harvest by providing transportation, marketing, and infrastructure support while the herd was rapidly increasing. In North America harvest is not normally used as a tool to control caribou population growth. More commonly, harvest restrictions are put in place to prevent further declines or reduce the time for populations to recover. If harvest is encouraged in North America, it is used as a tool to offset harvest from a declining herd by shifting harvest to an adjacent herd.

\section{Wolf management}

Active wolf management to reduce predation on caribou herds tends to be much more contentious in North America than in Russia (Schwartz et al. 2003). Aerial hunting of wolves, the most effective method identified in the Taimyr range, has limited application in North America, being restricted in recent decades to Alaska and a few jurisdictions in Canada. Currently in Alaska there is some parallel to Russia in the sense that control is often directed to enhancing ungulate harvest opportunities in accordance with an Intensive Management Law enacted in 1994 (Van Ballenberghe 2004). However, in Canada the rationale for wolf control is restricted to aid in the recovery of chronically low caribou populations (e.g., see Hayes et al. 2003). In the vast majority of wolf control programs in North America, the target caribou populations are woodland and mountain ecotypes, whereas few control programs are enacted to enhance low-density migratory tundra caribou populations. Further, we are unaware of any programs developed to facilitate aggressive commercial harvest of a rapidly expanding caribou population.

Data from this study were not rigorous enough to separate the relative impacts of wolf control and commercial harvest on the apparent stabilization of the Taimyr herd during the commercial period. Reviewing 24 North American studies, Adams et al. (2008) showed that the wolf population growth rate was not impacted with removal rates at $30 \%$ or lower. In other words, managers have no impact on the annual wolf population structure unless they take more than $30 \%$. It follows, therefore, that to be effective in recovering caribou populations, managers need to remove $65 \%-70 \%$ of the wolves for at least four years (Committee on Management of Wolf and Bear Populations in Alaska 1997).

\section{State versus local control}

Another lesson to be learned from the Taimyr situation is the contrast between strong management controls and the loss of that control after a sustained period of economic dependency on a wild reindeer resource. During the commercial period, infrastructure was built, the means to efficiently harvest wild reindeer were developed, equipment was purchased and deployed, and an economic dependency was created. In the postcommercial period, the state had no capability to either continue prior levels of management or the means to monitor what was happening in the population. As a result, the population is currently in decline, and a large unregulated harvest and unchecked wolf population appears to be major contributors to the decline.

\section{CONCLUSION}

The Taimyr wild reindeer population constitutes a critical natural resource in central Russia. Over the last six decades managers have reacted to natural and political challenges in the management of the herd. Slow population growth, expansion of 
range, and conflicts with domestic reindeer characterized the 1950-1970 period. Beginning in 1970, a decision was made to aggressively manage the herd to support local economies, prevent overgrazing, and reduce the conflicts with domestic reindeer. From 1970 to 1990, state agencies actively controlled wolves and supported commercial harvesting through the construction of infrastructure and subsidization of transportation and marketing. With the collapse of the Soviet Union in 1990, agencies lost most of their funding. As a result, commercial harvesting subsidies were halted, wolf control was stopped, and with limited personnel, enforcement was reduced. In the postcommercial period of 1991 to the present, the herd initially increased from the stable condition maintained between 1970 and 1990, peaking at 1 million animals in 2000. Since that peak, the herd has been declining and the experts maintain that wolf predation and unregulated harvest are the major factors in the decline. The experience in managing this large Rangifer herd during its increase and decrease phases offers some lessons for North America, especially with respect to the role of harvest and predation in the regulation of large migratory tundra herds.

Responses to this article can be read online at: http://www.ecologyandsociety.org/issues/responses. $\mathrm{php} / 7129$

\section{Acknowledgments:}

We are grateful to our friends and colleagues B. Pavlov, G. Jakushkin, V. Kuksov, and V. Zirjanov for their support and support for our work. We especially thank CARMA for providing the Russian authors with the opportunity to discuss the results of a study population of Taimyr wild reindeer with scientists from the northern countries. Dr. Gary Kofinas and anonymous reviewers provided many helpful comments in the review of this manuscript. Funding for much of this collaboration was through the U.S. National Science Foundation.

\section{LITERATURE CITED}

Adams, L. G., R. O. Stephenson, B. W. Dale, R. T. Ahgook, and D. J. Demma. 2008. Population dynamics and harvest characteristics of wolves in the Central Brooks Range, Alaska. Wildlife Monographs 170:1-25. http://dx.doi.org/10.2193/2008-012

Andreev, V. N. 1975. State of fodder base for reindeer husbandry and problems related to utilization of pastures by wild reindeer. Pages 60-70 in E. E. Syroechkovskii, editor. Wild reindeer of the Soviet Union. Translated in 1984 by the U.S. Department of the Interior. Amerind Publishing, New Delhi, India.

Baskin, L. M. 2005. Number of wild and domestic reindeer in Russia in the late 20th century. Rangifer 25(1):51-57. http://dx. doi.org/10.7557/2.25.1.337

Boertje, R. D., M. A. Keetch, and T. F. Paragi. 2010. Science and values influencing predator control for Alaska moose management. Journal of Wildlife Management 74(5):917-928. http://dx.doi.org/10.2193/2009-261

Committee on Management of Wolf and Bear Populations in Alaska, National Research Council. 1997. Wolves, bears, and their prey in Alaska: biological and social challenges in wildlife management. National Academy Press, Washington, D.C., USA.

Geller, M. K., and B. B. Borzhonov. 1975. Migrations and seasonal distribution of the reindeer populations of the Taimyr. Pages 71-79 in E. E. Syroechkovskii, editor. Wild reindeer of the Soviet Union. Translated in 1984 by the U.S. Department of the Interior. Amerind Publishing, New Delhi, India.

Gunn, A. 2003. Voles, lemmings and caribou-population cycles revisited? Rangifer 23(Special Issue No. 14):105-111. http://dx. doi.org/10.7557/2.23.5.1689

Hayes, R. D., R. Farnell, R. M. P. Ward, J. Carey, M. Dehn, G. W. Kuzyk, A. M. Baer, C. L. Gardner, and M. O’Donoghue. 2003. Experimental reduction of wolves in the Yukon: ungulate responses and management implications. Wildlife Monographs 152:1-35.

Klein, D. R., and L. A. Kolpaschikov. 1991. Current status of the Soviet Union's largest caribou herd. Pages 251-255 in C. E. Butler and S. P. Mahoney, editors. 4th North American Caribou Workshop, St. John's Newfoundland, October 31-November 3, 1989 Proceedings. Newfoundland and Labrador Wildlife Division, St. John's, Newfoundland, Canada.

Klokov, K. 2004. Pages 55-94 in B. Ulvevadet and K. Klokov, editors. Family-based reindeer herding and hunting economies, and the status and management of wild reindeer/caribou populations [title translated from the Russian]. Arctic Council. Centre for Sami Studies, University of Tromsø, Norway.

Klokov, K. B. 1997. Northern reindeer of Taymyr Okrug as the focus of economic activity: contemporary problems of reindeer husbandry and the wild reindeer hunt. Polar Geography 21:233-271. http://dx.doi.org/10.1080/10889379709377629

Kofinas, G. P., and D. E. Russell. 2004. North America. Pages 21-54 in B. Ulvevadet and K. Klokov, editors. Family-based reindeer herding and hunting economies, and the status and management of wild reindeer/caribou populations. Arctic Council. Centre for Sami Studies, University of Tromsø, Norway.

Kolpaschikov, L. A. 1974. On the nutrition of wild reindeer. Scientific and Technical Information 3-4:63-64.

Kolpaschikov, L. A., V. A. Kuksov, and B. M. Pavlov. 1983. The ecological rationale for limiting population size [title translated from the Russian]. Pages 3-14 in B. M. Pavlov, editor. Ecology and rational use of terrestrial vertebrates of the North Central Siberia. SO RASXN, Novosibirsk, Russia.

Kolpaschikov, L. A., and V. V. Mikhailov. 2001. Natural mortality of the Taimyr reindeer population [title translated from the Russian]. Zoological Journal 4:484-493.

Kolpaschikov, L. A., and V. V. Mikhailov. 2002. Commercial hunting, as a form of rational use and management of Taymir wild reindeer population [title translated from the Russian]. Pages 33-43 in K. A. Laishev, editor. Environmental issues of nature in the Far North. SO RASXN, Novosibirsk, Russia.

Kolpaschikov, L. A., and A. D. Muhachev. 2010. Yenisei north: reindeer and wolves [title translated from the Russian]. Pages 59-66 in V. M. Zelensky, editor. Biological resources of the Far North: the study and use. GUAP, Saint-Petersburg, Russia. 
Kolpaschikov, L. A., G. D. Yakushkin, and Y. I. Kokorev. $2003 a$. The results of the 2000 census of wild reindeer on the Taimyr Peninsula. Rangifer 23(Special Issue No. 14):197-200. http://dx. doi.org/10.7557/2.23.5.1701

Kolpaschikov, L. A., G. D. Yakushkin, Y. I. Kokorev, and V. V. Mikhailov. 2003b.Current status of the Taimyr reindeer population [title translated from the Russian]. Pages 52-60 in N. V. Lovelius, editor. Taimyr: biological resources and the prospects for their use. Asterion, Saint Petersburg, Russia.

Laishev, K. A., A. D. Mukhachev, L. A. Kolpaschikov, V. M. Zelenski, and I. N. Pikuleva. 2002. Taimyr reindeer [title translated from the Russian]. SO RASXN, Novosibirsk, Russia.

Laws, R. M. 1952. A new method of age determination for mammals. Nature 169:972-973 http://dx.doi.org/10.1038/169972b0

Mikhailov V. V., and L. A. Kolpaschikov. 2012. Three stages of the recorded history of the Taimyr reindeer population. Zoological Journal 91(4):486-492.

Mikhailov V. V., L. A. Kolpaschikov, and A. M. Shapkin. 2008. Problems of control and managements of wild reindeer population in the contemporary socio-economic conditions [title translated from the Russian]. Pages 23-36 in K. A. Laishev, editor. Biological resources of the Far North. GUAP, Saint Petersburg, Russia.

Mukhachev, A. D. 1975. Some problems of mophometric characteristics of domesticated and wild reindeer. Pages 80-89 in E. E. Syroechkovskii, editor. Wild reindeer of the Soviet Union. Translated in 1984 by the U.S. Department of the Interior. Amerind Publishing, New Delhi, India.

Nuttall, M., F. Berkes, B. Forbes, G. Kofinas,T. Vlassova, and G. Wenzel 2012. Climate change impacts on indigenous peoples of the Russian North. In C. J. Cleveland, editor. Encyclopedia of earth. Environmental Information Coalition, National Council for Science and the Environment, Washington, D.C., USA. [online] URL: http://www.eoearth.org/view/article/151245/

Pavlov, B. M., V. D. Saveliev, and V. A. Kuksov. 1976. Rational use of resources deer. Methodical recommendations [title translated from the Russian]. SO RASXN, Novosibirsk, Russia.

Pikuleva, I. N., and E. C. Zhiganova. 2003. The dynamics of lichen pastures in the Taimyr autonomous district [title translated from the Russian]. Pages 129-139 in N. V. Lovelius, editor. Taimyr: biological resources and the prospects for their use. Asterion, Saint Petersburg, Russia.

Roslyakov, A. P. 1975. Rational utilization of the natural resources of the Taimyr. Pages 235-239 in E. E. Syroechkovskii, editor. Wild reindeer of the Soviet Union. Translated in 1984 by the U.S. Department of the Interior. Amerind Publishing, New Delhi, India.

Russell, D. E., and B. Ulvevadat. 2004. Conclusion. Pages 151-158 in B. Ulvevadet and K. Klokov, editors. Family-based reindeer herding and hunting economies, and the status and management of wild reindeer/caribou populations. Arctic Council. Centre for Sami Studies, University of Tromsø, Norway.

Schwartz, C. C., J. E. Swenson, and S. M. Miller. 2003. Large carnivores, moose and humans: a changing paradigm of predator management in the 21st century. Alces 39:41-63.
Shelkunova, R. P. 1982. Zonal distribution of forage phytomass on the Taimyr [title translated from the Russian]. Botany Journal 62:479-491

Shelkunova, R. P. 2000. Vegetation and forage resources of Taimyr reindeer [title translated from the Russian]. Agrarnaja Russia 3:36-38.

Skrobov, V. D. 1975. Human intervention and wild reindeer. Pages 90-94 in E. E. Syroechkovskii, editor. Wild reindeer of the Soviet Union. Translated in 1984 by the U.S. Department of the Interior. Amerind Publishing, New Delhi, India. Amerind Publishing, New Delhi, India.

Suvorov, A. P. 2001a. On the strategy of regulating the wolves population; selectivity of wolves' cropping [title translated from the Russian]. Pages 45-50 in V. V. Korolev, editor. Scientific and technical achievements for the developments of Siberian regions. Era, Krasnoyarsk, Russia.

Suvorov, A. P. 2001b. On the ecology of the Yeniseyan North polar wolves: results and perspectives of Siberian Territory [title translated from the Russian]. Pages 163-167 in A. P. Demidovich, editor. Proceedings of scientific inter-region conference. Terriology Society, Irkutsk, Russia.

Suvorov, A. P. 2003. The Evenk wolves. Hunting and Hunting Industry 8:22-23.

Suvorov, A. P. 2005. Wolf hunting. Era, Moscow, Russia.

Syroechkovskii, E. E., editor. 1975. Wild reindeer of the Soviet Union. Translated in 1984 by the U.S. Department of the Interior. Amerind Publishing, New Delhi, India.

Syroechkovskii, E. E. 1995. Wild reindeer. Translated by the Smithsonian Institute Libraries. Amerind Publishing, New Delhi, India.

Van Ballenberghe, V. 2004. Biological standards and guidelines for predator control in Alaska: application of the National Research Council's recommendations. Paper presented at 2004 Carnivore Conference, November 16, 2004 in Santa Fe, New Mexico, USA. Defenders of Wildlife, Washington, D.C., USA. [online] URL: http://www.defenders.org/resources/publications/programs and policy/ wildlife conservation/imperiled species/wolf/alaska wolf/ guidelines and standards for predator control in alaska.pdf

Yakushkin, G. D., B. M. Pavlov, M. K. Geller, V. A. Zyryanov, V. D. Savel'ev, V. A. Kuksov, and B. B. Borzhanov. 1975a. Population and ecological characteristics and future study of wild reindeer of Taimyr. Pages 47-53 in E. E. Syroechkovskii, editor. Wild reindeer of the Soviet Union. Translated in 1984 by the U.S. Department of the Interior. Amerind Publishing, New Delhi, India.

Yakushkin, G. D., B. M. Pavlov, V. D. Savel'ev, V. A. Zyryanov, and V. A. Kuksov. 1975b. Biological principles of commercial utilization of wild reindeer in Northern Krasnoyarsk Region. Pages 225-229 in E. E. Syroechkovskii, editor. Wild reindeer of the Soviet Union. Translated in 1984 by the U.S. Department of the Interior. Amerind Publishing, New Delhi, India.

Yakushkin G. D., L. A. Kolpaschikov, and Y. I. Kokorev. 2001. Great population [title translated from the Russian]. Hunting and Hunting Industry 5:5-7. 